\title{
The Influence of High-heeled Shoes on Kinematics and Kinetics of the Knee Joint during Sit-to-stand task
}

\author{
Ji-Won Park', Yun-Jin Kim² \\ 'Department of Physical Therapy, College of Medical Science, Catholic University of Daegu; ${ }^{2}$ Department of Physical Therapy, General Graduate \\ School, Catholic University of Daegu, Daegu, Korea
}

Purpose: The purpose of this study was to examine the change in the kinematics and kinetics of the knee joint depending on high-heeled shoes during sit-to-stand (SitTS) task.

Methods: Nineteen healthy females participated in this study. The subjects performed the SitTS task wearing high-heeled shoes and barefoot. The experiment was repeated three times for each task with foot conditions. The kinematics and kinetics of the knee joint were measured and analyzed using a 3D motion analysis system.

Results: The result of this study showed kinematic and kinetics differences in knee joints during the SitTS task based on high-heeled shoes. Significant differences in knee flexion angle were observed during SitTS. The knee extensor force showed statistically significant differences during SitTS tasks. At the initial of SitTS, the knee flexor and extensor moment showed significant differences. The knee extensor moment showed statistically significant differences at the terminal of SitTS. At the maximum of SitTS, the knee extensor moment showed statistically significant differences.

Conclusion: Therefore, wearing high-heeled shoes during SitTS movements in daily life is considered to influence knee joint kinematics and kinetics due to the $\mathrm{HH}$, suggesting the possibility of increased risk of patellofemoral pain, and knee osteoarthritis caused by changes in loading of the knee joint.

Keywords: Knee joint, High-heeled shoes, Sit-to-stand

\section{서 론}

무릎-넙다리통증증후군과 무릎관절염은 일반적인 근육뼈대계 질환 이며, ${ }^{1} 50$ 세 이상의 여성에게서 상당히 많이 증가함에 따라 남성에 비 해 약 두 배 더 많이 나타난다. ${ }^{2}$ 신발은 무릎관절염의 발달 및 진행 정 도를 잠재적으로 조절하고, 쉽게 변형할 수 있는 요인으로, ${ }^{3,4}$ 목적에 따라 패션을 위한 구두, 치료 중재의 목적으로 한 신발 내 삽입물 ${ }^{5}$ 등 다양한 형태의 신발 착용이 무릎관절염의 발달 및 진행에 영향을 줄 수 있는 가능성이 있다. 여성과 남성은 맨발로 걷는 동안에는 유사한 무릎관절의 운동역학이 나타나기 때문에, 특히 여성만이 착용하는 신발인 하이힐은 여성 무릎관절염의 높은 발생빈도수의 원인이 될 수 있음을 보여준다. ${ }^{4,6}$ 최근 젊은 여성은 외적인 모습을 위해 낮은-굽 신발보다 높은-굽 신발을 착용하는 것을 선호한다고 하였고, ${ }^{7}$ 일상생 활 중에 이를 신고 생활하며 보행을 한다. ${ }^{89}$ 그러나, 하이힐을 착용하
는 많은 여성들은 경미한 것부터 중증의 통증을 겪고 있다고 한다. ${ }^{10}$

하이힐 착용은 보행의 운동형상학과 운동역학을 변형시키는데, 보행 속도를 느리게, 보폭 길이를 짧아지게 한다.11,12 또한, 보행 시 지 면에 닿는 순간 충격 힘을 생성하여 뼈대에 전달하는데, ${ }^{12}$ 이러한 변 형된 힘으로 인하여 퇴행성 관절손상을 유발시킨다. ${ }^{11}$ 특히, 일부 연 구자들은 하이힐 착용이 무릎 통증과 관절염의 발달 및 진행에 기여 할 수 있고, ${ }^{13}$ 근 활성도 패턴을 변형시킬 수 있음을 제안했다. ${ }^{14,15}$ 구두 굽 높이가 증가함에 따라, 무릎 운동형상학적 변화는 초기 입각기에 서 굽힘이 증가했고, ${ }^{16}$ 운동역학적 변화로는 최대 외부 굽힘 모멘트 증가하였으며, ${ }^{4,16}$ 외부 폄 모멘트의 두 번째 최댓값은 감소하였다. ${ }^{16}$ 이 러한 변형된 무릎관절 굽힘-폄 각도와 모멘트의 특정 수치는 노화와 관절염 진행과 관련되어 있다. ${ }^{17}$

많은 사람들은 신발을 착용하여 일상생활을 하며, 보행을 비롯한 다양한 기능적인 활동을 수행하는데, 특히 앉은 자세에서 일어서기
Received Sep 15, 2015 Revised Oct 4, 2015

Accepted Oct 25, 2015

Corresponding author Yun-Jin Kim

E-mail jin1205love@naver.com
Copylight (C)2015 The Korea Society of Physical Therapy

This is an Open Access article distribute under the terms of the Creative Commons Attribution Non-commercial License (Http:// creativecommons.org/license/by-nc/3.o.) which permits unrestricted non-commercial use, distribution, and reproduction in any medium, provided the original work is properly cited. 
(sit-to-stand) 동작은 일상적인 움직임으로, ${ }^{18}$ 일상생활에서 가장 일반 적으로 요구되는 기능적 과제이다. ${ }^{19}$ 선행연구에서는 앉은 자세에서 일어서기 동작이 무릎관절의 기능을 평가하는데, 탁월하고 기능적 으로 유효한 평가방법이라고 평가하였으며, ${ }^{20}$ 이러한 동작은 특히 보 행과 계단 오르기 동작보다 엉덩관절과 무릎관절의 큰 모멘트가 필 요하다. ${ }^{21-23}$ 또한, 초기 착석자세가 변경될 때는 관련된 근육들의 작 용 패턴이 달라지며, ${ }^{24}$ 이러한 동작을 수행하는 동안 하이힐 착용하 는 것은 신경근 조절과 자세 변화, 그리고 요통에 영향을 미칠 수 있 을 것이다.25

최근까지 이루어진 선행 연구들을 살펴보면, 하이힐 착용에 따른 무릎관절의 운동형상학 및 운동역학적 변화 연구, $34,13,26$ 구두 굽 높이 에 따른 다리 관절의 운동형상학적 및 운동역학적에 관한 연구 14,15 등 비교적 다양한 분야의 연구들이 이루어지고 있으나, 위의 많은 선행 연구에서는 대부분 하이힐 착용이 보행을 수행하는 동안 운동형상 학 및 운동역학적 변화에 미치는 영향에 초점을 두었다. ${ }^{25}$ 또한, 앉은 자세에서 일어서기 동작을 수행하는 동안 하이힐 착용에 관한 연구 는 몸통과 다리의 근전도와 운동형상학, 안쪽넓은근과 가쪽넓은근 의 활성도 비교 ${ }^{10}$ 등으로 남성에 비해 여성의 무릎넙다리통증증후군 과 관절염의 유병률이 높음에도 불구하고, 하이힐 착용에 따른 일어 서기 동작 시 무릎관절의 운동형상학 및 운동역학적인 관점의 연구 는 아직 미흡한 것으로 나타났다.

따라서 본 연구는 건강한 성인 여성을 대상으로 앉은 자세에서 일 어서기 동작을 수행하는 동안 3 차원 동작 분석기를 통해 운동형상 학, 운동역학적인 관점으로 무릎관절 부하에 미치는 영향에 대해 알 아보고, 이러한 동작 수행 동안 하이힐 착용에 따른 무릎관절염에 대 한 위험성과 관련하여 규명하며, 임상 평가 및 치료중재를 위한 기초 자료로 제시하고자 한다.

\section{연구방법}

\section{1. 연구대상 및 기간}

본 연구는 대구가톨릭대학교에 재학 중인 건강한 성인 여성 19 명을 대상으로 실시하였다. 모든 대상자들은 손을 사용하지 않고, 표준 의 자에서 독립적으로 앉고 일어설 수 있으며, ${ }^{27}$ 우성 발이 오른발인 자 (right-footed)로 차기 동작(kicking)을 수행할 때 사용하는 다리로 오 른쪽 다리를 선호하는 자로 선정했다. ${ }^{28}$ 또한, 최근 1 년간 다리의 근육 뼈대계 이상, 선천적인 기형 및 정형외과적 질환이나 변형, 신경학적 으로 손상이 있는 자는 본 연구에서 제외하였다. 본 연구에 참여한 대상자들은 실험하기 전, 전 과정에 대해 충분한 설명을 듣고 실험 참 여에 자발적으로 동의를 하였다.

\section{2. 실험방법}

1) 측정도구

(1) 무릎관절 운동형상학 및 운동역학 측정

3 차원 동작 분석기(Motion analysis corp, santarosa, CA, US)는 8 개의 적외선카메라로 구성되어있고, cortex motion capture software 1.1.4.386 프로그램을 이용하여 카메라 프레임 비율 $120 \mathrm{~Hz}$ 에서 기능 적인 동작을 수행하는 동안 대상자의 무릎관절 운동형상학 및 운동 역학적 움직임을 측정하였다. 무릎관절의 움직임을 측정하기 위해 사용한 3 차원 동작 분석기의 표식자(marker)는 Helen-hayes market set 방법으로 부착하였으며, 부착부위는 다음과 같다. 위앞엉덩뼈가시 (ASIS), 위뒤엉덩뼈가시(PSIS), 엉치뼈(sacral), 넙다리(thigh), 안쪽 무릎 (medial knee), 가쪽 무릎(lateral knee), 정강이(shank), 안쪽복사(medial malleolus), 가쪽복사(lateral malleolus), 발뒤꿈치(heel), 두 번째와 세 번 째 발가락 사이(toe)이다. 엉치뼈를 제외한 나머지 부위는 양쪽으로 부착하여 총 21 개의 표식자를 이용하였다.

\section{(2) 실험용 신발}

본 연구에 사용한 실험용 신발은 하이힐(high-heeled shoes, HH)이다. 하이힐의 굽 높이는 $9 \mathrm{~cm}$ 이며, 대상자 모두 동일한 신발 형태의 하이 힐을 착용하였다.

\section{(3) 동작별 제어 도구}

본 연구에 사용한 동작별 제어 도구는 의자(chair)이다. 의자는 팔걸 이와 등받이가 없고, 의자 높이는 각각의 대상자마다 맨발로 앉았을 때 지면에서 넙다리뼈 가쪽관절융기까지의 거리만큼 조절하였다. ${ }^{27}$

\section{2) 실험절차}

대상자들은 실험을 수행하기 전 나이, 신장, 체중, 발 길이, 발 너비 등 의 측정을 하였다. 대상자는 맨발(barefoot, $\mathrm{BF}$ )과 하이힐 착용 조건별 일어서기 동작을 3 번씩 반복 수행하였다. 실험 조건들은 맨발과 $9 \mathrm{~cm}$ 굽 높이의 하이힐이고, 실험 동작은 의자에 앉은 자세에서 일어서기 동작을 수행하였다. 본 실험의 모든 대상자들의 맨발 조건과 하이힐 착용조건은 무작위 순서로 실험 조건별 동작을 반복 수행하였고, 동 작들 사이에 3 분 혹은 피로도를 느끼지 않는 만큼의 휴식시간이 주 어졌다.

3) 앉은 자세에서 일어서기 동작(sit-to-stand task, SitTS task) 대상자의 시작자세는 팔을 몸통에 교차해서 의자에 앉은 자세이다. 대상자는 청각적 신호를 들으면 앉은 자세에서 일어서는 동작을 수행 한 후, ${ }^{9}$ 선 자세를 약 5 초 유지한 다음에 다시 앉는 동작을 수행한다. ${ }^{27}$ 


\section{4) 자료수집}

본 연구의 무릎관절 운동형상학 및 운동역학적 자료는 다음과 같은 시점에서 수집하였다.

앉은 자세에서 일어서기 동작을 수행하는 동안 동작의 시작자세, 동작 주기의 최댓값, 마지막 자세이다. 운동형상학 및 운동역학적 자 료는 우성측의 무릎관절의 굽힘 각도(angle), 굽힘 모멘트(moment), 힘(force)값이며, 모든 자료는 평균값을 수집하였다.

\section{3. 통계 분석}

무릎관절의 평균 각도 자료는 SIMM biomechanics software 6.0.2 프로 그램으로 분석하였고, 통계처리는 PASW 18.0 프로그램을 이용하였 다. 연구 대상자의 일반적인 특성은 기술통계량의 빈도분석으로 분 석하였고, 앉은 자세에서 일어서기와 선 자세에서 앉기 동작 시 하이 힐 착용에 따른 우성측 무릎관절의 운동형상학 및 운동역학적 평균 값을 비교하기 위해 대응표본 T 검증(paired t-test)을 사용하였다. 통 계학적 유의수준 $\alpha=0.05$ 로 설정하였다.

\section{결 과}

\section{1. 연구 대상자의 일반적인 특성}

본 연구에 참여한 대상자는 여성 19명이며, 평균 나이 22.6세, 키 160.3 $\mathrm{cm}$, 체중 $50.2 \mathrm{~kg}$, 우성 발 길이 $23.5 \mathrm{~cm}$, 우성 발 너비 $9.0 \mathrm{~cm}$ 였다.

\section{2. 무릎관절 운동형상학(kinematics)}

1) 앉은 자세에서 일어서기 동작 시 무릎관절 굽힘 각도(knee flexion angle $\left.\left({ }^{\circ}\right)\right)$

앉은 자세에서 일어서기 동작 시 시작 지점에서는 하이힐 착용 시 무 릎관절 굽힘은 증가하였고, 유의한 차이가 있었다 $(\mathrm{p}<0.05)$. 마지막 지 점에서는 맨발보다 하이힐 착용에 따른 무릎관절 폄 각도가 감소하 였으며, 동작 수행 동안 굽힘 각도의 최대값은 맨발보다 하이힐 착용 시 증가하였고, 유의한 차이가 있었다 $(\mathrm{p}<0.05)$ (Table 1).

Table 1. Sit-to-stand task of knee flexion angle $\left(^{\circ}\right)$

\begin{tabular}{llrrc}
\hline Task (event) & & \multicolumn{1}{c}{ BF } & HH & p \\
\hline SitTS & Initial & $90.94 \pm 6.98$ & $96.69 \pm 6.20$ & $0.000^{*}$ \\
& Terminal & $-2.86 \pm 2.85$ & $-1.75 \pm 2.69$ & $0.008^{*}$ \\
& $\begin{array}{l}\text { Flexion angle } \\
\text { (maximum) }\end{array}$ & $92.53 \pm 6.92$ & $103.94 \pm 6.17$ & $0.000^{*}$ \\
& & & & \\
\hline
\end{tabular}

Values are mean \pm SD

SitTS: Sit-to-stand task, BF: Barefoot group, HH: High-heeled shoes group, SM: Semimembranosus, ST: Semitendinosus, BFL: Biceps femoris-long head, BFS: Biceps femoris-short head, RF: Rectus femoris, VM: Vastus medialis, VI: Vastus intermedialis, VL: Vastus lateralis.

${ }^{*} p<0.05$.

\section{3. 앉은 자세에서 일어서기 동작 시 무릎관절 운동역학(kinetics)}

1) 무릎관절 근육 힘(force, N)

앉은 자세에서 일어서기 동작 시 시작 지점에서는 맨발과 하이힐 착 용에 따른 반막근과 반힘줄근, 넙다리두갈래근의 긴갈래의 힘에서 는 유의한 차이가 없었지만, 넙다리두갈래근의 짧은갈래의 힘은 하 이힐 착용 시 감소하면서 유의한 차이가 있었다 $(\mathrm{p}<0.05)$. 맨발과 하 이힐 착용에 따른 넙다리곧은근의 힘은 유의한 차이가 없었지만, 중 간넓은근과 안쪽넓은근, 가쪽넓은근의 힘은 하이힐 착용 시 모두 감 소하면서 유의한 차이가 있었다 $(\mathrm{p}<0.05)$.

동작 수행 시 마지막 지점에서는 맨발과 하이힐 착용에 따른 반막 근, 반힘줄근, 넙다리두갈래근의 긴갈래와 짧은갈래의 힘은 모두 유 의한 차이가 없었으며, 넙다리곧은근, 중간넓은근, 안쪽넓은근, 가쪽 넓은근의 힘은 하이힐 착용시 모두 증가하면서 유의한 차이가 있었 다 $(\mathrm{p}<0.05)$.

동작 수행 동안 힘의 최댓값에서는 맨발과 하이힐 착용에 따른 반 막근, 반힘줄근, 넙다리두갈래근의 긴갈래와 짧은갈래, 넙다리곧은 근, 중간넓은근과 가쪽넓은근의 힘은 모두 유의한 차이가 없었으며, 안쪽넓은근의 힘만 하이힐 착용 시 감소하면서 유의한 차이가 있었 다 $(\mathrm{p}<0.05)$ (Table 2).

\section{2) 무릎관절 모멘트(moment, $\mathrm{N}-\mathrm{m}$ )}

앉은 자세에서 일어서기 동작 시 시작 지점에서는 맨발과 하이힐 착 용에 따른 반막근의 내부 무릎관절 굽힘근 모멘트에서는 유의한 차 이가 없었지만, 하이힐 착용 시 반힘줄근과 넙다리두갈래근의 긴갈 래와 짧은갈래의 내부 무릎관절 굽힘근 모멘트는 감소하면서 유의 한 차이가 있었다 $(\mathrm{p}<0.05)$. 하이힐 착용 시 넙다리곧은근과 중간넓 은근, 안쪽넓은근과 가쪽넓은근의 내부 무릎관절 폄근 모멘트는 감 소하면서 유의한 차이가 있었다 $(\mathrm{p}<0.05)$.

동작 수행 시 마지막 지점에서는 하이힐 착용 시 넙다리곧은근의 내부 무릎관절 폄근 모멘트에서만 증가하면서 유의한 차이가 있었 다. 반막근, 반힘줄근, 넙다리두갈래근의 긴갈래와 짧은갈래, 중간넓 은근, 안쪽넓은근, 가쪽넓은근의 내부 모멘트에서는 모두 유의한 차 이가 없었다.

동작 수행 동안 내부 모멘트의 최댓값은 하이힐 착용 시 반막근의 내부 무릎관절 굽힘근 모멘트에서는 감소하면서 유의한 차이가 있었 지만 $(\mathrm{p}<0.05)$, 반힘줄근과 넙다리두갈래근의 긴갈래와 짧은갈래의 내부 무릎관절 굽힘근 모멘트 유의한 차이가 없었다. 하이힐 착용 시 넙다리곧은근의 내부 무릎관절 폄근 모멘트는 유의한 차이가 없었 고, 중간넓은근, 안쪽넓은근과 가쪽넓은근은 모두 증가하면서 유의 한 차이가 있었다 $(\mathrm{p}<0.05)$ (Table 3$)$. 
Table 2. Sit-to-stand task of knee joints (force (N))

\begin{tabular}{|c|c|c|c|c|}
\hline Task (event) & Muscle & $\mathrm{BF}$ & $\mathrm{HH}$ & $\mathrm{p}$ \\
\hline \multirow[t]{8}{*}{ SitTS (initial) } & SM & $505.36 \pm 189.02$ & $541.10 \pm 167.49$ & 0.390 \\
\hline & ST & $295.61 \pm 16.85$ & $296.47 \pm 17.38$ & 0.324 \\
\hline & $\mathrm{BFL}$ & $583.71 \pm 53.23$ & $572.74 \pm 41.20$ & 0.467 \\
\hline & BFS & $263.78 \pm 11.99$ & $228.40 \pm 16.90$ & $0.000^{*}$ \\
\hline & RF & $669.78 \pm 66.43$ & $651.71 \pm 84.29$ & 0.106 \\
\hline & VM & $1,124.40 \pm 59.25$ & $1,063.85 \pm 59.33$ & $0.000^{*}$ \\
\hline & $\mathrm{Vl}$ & $1,163.77 \pm 69.07$ & $1,101.22 \pm 70.30$ & $0.000^{*}$ \\
\hline & VL & $1,598.05 \pm 82.69$ & $1,508.17 \pm 84.61$ & $0.000^{*}$ \\
\hline \multirow[t]{8}{*}{ SitTS (terminal) } & SM & $483.89 \pm 161.42$ & $459.69 \pm 139.25$ & 0.176 \\
\hline & ST & $296.67 \pm 18.68$ & $296.39 \pm 18.38$ & 0.296 \\
\hline & BFL & $589.64 \pm 48.71$ & $586.91 \pm 44.65$ & 0.442 \\
\hline & BFS & $336.04 \pm 18.94$ & $336.04 \pm 18.96$ & 0.831 \\
\hline & RF & $546.57 \pm 95.35$ & $574.45 \pm 70.78$ & $0.017^{*}$ \\
\hline & VM & $152.59 \pm 70.45$ & $182.65 \pm 74.60$ & $0.010^{*}$ \\
\hline & $\mathrm{Vl}$ & $168.60 \pm 77.95$ & $201.78 \pm 82.35$ & $0.010^{*}$ \\
\hline & $V L$ & $190.39 \pm 95.30$ & $231.52 \pm 103.53$ & $0.011^{*}$ \\
\hline \multirow{8}{*}{$\begin{array}{l}\text { SitTS } \\
\quad \text { (maximum force) }\end{array}$} & SM & $861.00 \pm 46.00$ & $841.61 \pm 50.95$ & 0.052 \\
\hline & ST & $299.49 \pm 18.94$ & $299.50 \pm 18.95$ & 0.745 \\
\hline & BFL & $655.78 \pm 40.56$ & $651.46 \pm 39.39$ & 0.109 \\
\hline & BFS & $336.07 \pm 18.93$ & $336.05 \pm 18.96$ & 0.151 \\
\hline & RF & $676.35 \pm 59.69$ & $672.87 \pm 60.57$ & 0.629 \\
\hline & VM & $1,190.64 \pm 76.94$ & $1,190.67 \pm 77.10$ & 0.656 \\
\hline & $\mathrm{VI}$ & $1,260.44 \pm 23.28$ & $1,260.22 \pm 23.24$ & $0.045^{*}$ \\
\hline & VL & $1,720.66 \pm 110.49$ & $1,729.56 \pm 110.45$ & 0.219 \\
\hline
\end{tabular}

Values are mean \pm SD.

SitTS: Sit-to-stand task, BF: Barefoot group, HH: High-heeled shoes group, SM: Semimembranosus, ST: Semitendinosus, BFL: Biceps femoris-long head, BFS: Biceps femoris-short head, RF: Rectus femoris, VM: Vastus medialis, Vl: Vastus intermedialis, VL: Vastus lateralis.

${ }^{*} p<0.05$.

\section{고 찰}

본 연구는 건강한 성인 여성을 대상으로 앉은 자세에서 일어서기 동 작 시 맨발과 비교하여 하이힐 착용이 무릎관절 부하에 미치는 영향 을 알아보고자 하였다. 동작을 수행하는 동안 맨발(barefoot)과 하이 힐(high-heeled shoes) 착용에 따른 무릎관절의 운동형상학, 운동역학 적인 변화는 3 차원 동작 분석 시스템을 통해 측정 및 분석을 하였다.

신발은 퇴행성 무릎관절염의 발달 및 진행 정도를 잠재적으로 조 절하고, 쉽게 변형할 수 있는 요인으로, ${ }^{3,4}$ 최근 젊은 여성들은 외적인 모습을 위해 하이힐을 착용하는 것을 선호하며, 이를 신고 생활하며 보행을 한다. ${ }^{89}$ 남성에 비해 여성의 무릎넙다리통증과 퇴행성 무릎관 절염의 유병률이 높음에도 불구하고, 일어서기와 앉는 동작 시 하이 힐 착용에 따른 무릎관절의 운동형상학 및 운동역학적인 관점의 연 구는 아직 미흡한 것으로 나타났다. 이에 본 연구는 하이힐 착용 시 우성측 무릎관절의 각도(angle), 모멘트(moment), 힘(force)을 일어서
Table 3. Sit-to-stand task of knee joints (moment $(\mathrm{N}-\mathrm{m})$ )

\begin{tabular}{|c|c|c|c|c|}
\hline Task (event) & Muscle & $\mathrm{BF}$ & $\mathrm{HH}$ & $p$ \\
\hline \multirow[t]{8}{*}{ SitTS (initial) } & SM & $15.97 \pm 6.58$ & $14.40 \pm 5.71$ & 0.263 \\
\hline & ST & $9.29 \pm 1.01$ & $7.33 \pm 1.04$ & $0.000^{*}$ \\
\hline & BFL & $28.41 \pm 2.84$ & $26.52 \pm 2.75$ & $0.036^{*}$ \\
\hline & BFS & $12.35 \pm 0.96$ & $10.71 \pm 0.92$ & $0.000^{*}$ \\
\hline & RF & $-15.48 \pm 2.06$ & $-13.90 \pm 2.31$ & $0.000^{*}$ \\
\hline & VM & $-28.53 \pm 3.05$ & $-25.67 \pm 3.34$ & $0.000^{*}$ \\
\hline & $\mathrm{VI}$ & $-27.53 \pm 3.19$ & $-24.42 \pm 3.02$ & $0.000^{*}$ \\
\hline & $V L$ & $-38.86 \pm 4.00$ & $-33.63 \pm 3.57$ & $0.000^{*}$ \\
\hline \multirow[t]{8}{*}{ SitTS (terminal) } & SM & $9.24 \pm 3.31$ & $9.08 \pm 2.96$ & 0.683 \\
\hline & ST & $7.52 \pm 0.93$ & $7.67 \pm 0.76$ & 0.105 \\
\hline & BFL & $5.07 \pm 4.31$ & $4.74 \pm 1.43$ & 0.701 \\
\hline & BFS & $0.43 \pm 2.11$ & $0.30 \pm 0.71$ & 0.756 \\
\hline & $\mathrm{RF}$ & $27.30 \pm 5.62$ & $-28.78 \pm 4.40$ & $0.023^{*}$ \\
\hline & VM & $-7.97 \pm 4.59$ & $-8.51 \pm 3.20$ & 0.479 \\
\hline & $\mathrm{Vl}$ & $-8.69 \pm 4.63$ & $-8.51 \pm 3.20$ & 0.807 \\
\hline & $V L$ & $-10.10 \pm 6.35$ & $-10.82 \pm 4.51$ & 0.498 \\
\hline \multirow{8}{*}{$\begin{array}{l}\text { SitTS } \\
\text { (maximum force) }\end{array}$} & SM & $32.29 \pm 3.00$ & $30.05 \pm 4.15$ & $0.005^{*}$ \\
\hline & ST & $12.83 \pm 1.38$ & $12.88 \pm 1.34$ & 0.247 \\
\hline & BFL & $32.50 \pm 3.18$ & $32.19 \pm 3.20$ & 0.052 \\
\hline & BFS & $13.06 \pm 1.34$ & $13.06 \pm 1.34$ & 0.057 \\
\hline & $\mathrm{RF}$ & $-10.06 \pm 4.22$ & $-10.20 \pm 3.75$ & 0.744 \\
\hline & VM & $-7.15 \pm 3.15$ & $-8.51 \pm 3.20$ & $0.010^{*}$ \\
\hline & $\mathrm{VI}$ & $-7.93 \pm 3.50$ & $-9.44 \pm 3.56$ & $0.010^{*}$ \\
\hline & $\mathrm{VL}$ & $-8.94 \pm 4.30$ & $-10.82 \pm 4.51$ & $0.011^{*}$ \\
\hline
\end{tabular}

Values are mean $\pm S D$.

SitTS: Sit-to-stand task, BF: Barefoot group, HH: High-heeled shoes group, SM: Semimembranosus, ST: Semitendinosus, BFL: Biceps femoris-long head, BFS: Biceps femoris-short head, RF: Rectus femoris, VM: Vastus medialis, VI: Vastus intermedialis, VL: Vastus lateralis.

${ }^{*} \mathrm{p}<0.05$.

기 동작의 해당시점에 따라알아보고자 하였다.

일반적으로, 무릎관절은 하이힐 착용 시 발을 지면에 닿았을 때뿐 만 아니라 입각기에서 좀 더 굽힘 각이 증가하며, 무릎과 발목의 관절 가동범위에 제한을 주는데, 보행 시 초기 입각기에서 무릎 굽힘 증가 와 발목 가쪽돌림(eversion)을 감소시킨다. 본 연구 결과에서도 앉은 자세에서 일어서기 동작 시 시작 시점, 마지막 지점, 그리고 동작 수행 동안 굽힘 각도의 최댓값은 맨발보다 하이힐 착용 시 굽힘 각이 모두 증가하였고, 유의한 차이가 있었다. 이는 하이힐 착용으로 인한 발목 의 발등굽힘 소실로 부분적인 보상작용으로 인해 힘이 집중되고, 무 릎뼈 힘줄 염좌, 무릎넙다리관절 및 정강이-넙다리뼈에 가해지는 부 하가 증가하여, 무릎관절 통증 및 퇴행성 변화에 기여할 수 있다.10,29

넙다리네갈래근의 근활성도는 입각기 동안 무릎 굽힘 증가로 인 해 증가하는데, ${ }^{1516}$ 하이힐 착용으로 인해 증가된 넙다리곧은근의 근 활성도는 무릎관절의 전방전달력을 증가시켜, 쉽게 무릎관절 통증 을 발생시킬 수 있을 것이다.30,31 무릎넙다리관절 반력 (넙다리네갈래 
근과 무릎인대 힘의 합력)은 넙다리네갈래근의 힘과 무릎관절 굽힘 각에 따라 증가하는데, ${ }^{29,32,33}$ 본 연구 결과에서도 앉은 자세에서 일어 서기 동작 수행 시 마지막 시점은 서 있는 자세로 넙다리곧은근, 중간 넓은근, 안쪽넓은근, 가쪽넓은근의 힘은 하이힐 착용 시 모두 증가하 면서 유의한 차이가 있었으며 $(\mathrm{p}<0.05)$, 무릎넙다리관절 반력이 증가 하여 무릎관절 통증을 유발시킬 수 있을 것이라 생각된다.

앉은 자세에서 일어서기 동작은 보행 및 계단보행과 비교했을 때 보다 더 큰 관절의 힘과 모멘트가 필요한데, 일어서는 능력을 결정하 는 것으로 무릎관절과 엉덩관절 폄근의 중요한 역할을 한다. ${ }^{21} \mathrm{Wre}-$ tenberg와 Aborelius ${ }^{22}$ 는 앉은 자세에서 일어서기 동안 엉덩관절과 무 릎관절 관절의 구심성 힘의 $72 \%$ 가 무릎 폄근에서 발생한다고 보고 하였고, Kotake 등 23 은 서 있는 자세에서 앉은 자세 동작을 수행할 때 에도 최소한의 관절 모멘트는 상대적으로 무릎과 엉덩관절 최대 폄 강도의 각각 $30 \%$ 와 $27 \%$ 를 필요로 한다고 보고했다. 닫힌 사슬에서의 무릎 굽힘 증가가 무릎 폄근 그룹의 근 활성도를 증가시키며, 발목 기 울기에 의해 외부 무릎 굽힘 모멘트가 증가한다고 보고하였다. ${ }^{34,35}$

하이힐 착용은 무릎 폄근 모멘트를 증가시키고, 이는 무릎넙다리 관절의 스트레스 증가를 야기시킨다. ${ }^{36}$ 다른 선행연구에서도 하이힐 이 넙다리곧은근 활성도를 증가시키고, ${ }^{15}$ 시상면의 무릎관절 토크를 증가시키며, 이러한 요인들은 퇴행성 관절발달에 기여하여 무릎넙다 리관절 내에 변화를 줄 수 있다고 보고하였다.13 본 연구 결과에서는 앉은 자세에서 일어서기 동작 시 마지막 시점인 선 자세에서 하이힐 착용 시 넙다리곧은근의 내부 무릎관절 폄근 모멘트가 증가하였으 며, 동작 수행 동안 내부 모멘트 최댓값은 하이힐 착용 시 중간넓은근, 안쪽넓은근과 가쪽넓은근의 내부 무릎관절 폄근 모멘트가 증가하면 서 모두 유의한 차이가 있었다 $(\mathrm{p}<0.05)$. 이러한 동작을 수행하는 동 안에도 하이힐 착용이 무릎관절 모멘트 값을 증가시켜, 선행연구와 일치하며 퇴행성 무릎관절염 발달을 야기시킬 수 있다고 생각된다.

계단 오르기와 스쿼트와 같은 무릎관절의 과도한 굽힘하는 동작 을 하는 동안 외부 무릎관절 굽힘 모멘트는 내측 부하에 중요한 영향 을 미치며, ${ }^{37}$ 굽힘 모멘트에 영향을 주는 신발 또는 신발 깔창은 외부 무릎관절 모음 모멘트와 모음 각도 충격량(angular impulse)에 영향 을 줄 수 있다. ${ }^{38}$ 이러한 연구자들에 따르면, 시상면과 관상면의 내부 모멘트 변화는 무릎관절 폄 근육들의 근활성도 증가와 관련이 있을 것이고, 무릎넙다리관절에 큰 스트레스를 주며 무릎뼈 움직임에 변 화를 줄 것이다. ${ }^{16,36}$ 외부 무릎 모음 모멘트 때문에 비대칭 하중 분포 로 무릎 안쪽 부위에 더 큰 부하가 나타나는데, 하이힐은 무릎관절의 외부 모음 모멘트를 증가시키고, 내측 부위에 부하를 증가시킨다고 보고했다. ${ }^{13}$ 이러한 무릎 모음 모멘트 증가는 무릎의 내측 부위에 많 은 스트레스를 유발하고, 시간이 지남에 따라 연골 퇴행성, 통증, 그 리고 골관절염을 야기시킬 수 있다. ${ }^{39}$ 본 연구에서 시행한 일어서기
동작 시 하이힐 착용에 대한 결과도 시상면의 무릎관절 내부 모멘트 변화가 나타났으며, 이로 인해 관상면의 내부 모멘트에 영향을 주며, 무릎 내측 부위의 퇴행성관절염 진행 정도와 중증도를 예측할 수 있 을 것으로 생각된다.

반면에, 다른 선행연구에서는 초기 착석자세가 변경될 때는 관련 된 근육들의 작용 패턴이 달라지며, ${ }^{24}$ 이러한 동작을 수행하는 동안 하이힐 착용하는 것은 신경근 조절과 자세 변화, 그리고 요통에 영향 을 미칠 수 있을 것이라고 보고하였다. ${ }^{25}$ 본 연구 결과에서는 앉은 자 세에서 일어서기 동작 시 시작 지점에서는 넙다리두갈래근의 짧은 갈래, 중간넓은근과 안쪽넓은근, 가쪽넓은근의 힘은 하이힐 착용 시 모두 감소하였고, 반힘줄근과 넙다리두갈래근의 긴갈래와 짧은갈래 의 내부 무릎관절 굽힘근 모멘트와 넙다리곧은근과 중간넓은근, 안 쪽넓은근과 가쪽넓은근의 내부 무릎관절 폄근 모멘트가 감소하면서 유의한차이가 있었다 $(\mathrm{p}<0.05)$. 이러한 결과는 다른 시점에서와는 다 른 관절 부하 패턴이 나타났으며, 하이힐 착용으로 인한 초기 착석 자 세의 변화가 관절 부하에 영향을 미친 것으로 생각된다.

또한, 다른 선행연구에서는 일어서기 동작의 문제가 있는 사람의 $44 \%$ 가 무릎 폄근 힘의 감소를 나타냈고, ${ }^{27,40}$ 폄근 그룹의 약화는 일어 서기와 앉은 동작에 필요한 높은 관절 모멘트와 힘을 생산하는 능력 의 제한을 나타낸다고 보고했으며, 본 연구 결과로 하이힐 착용으로 인한 초기 착석자세 변화가 향후에 폄근 그룹의 약화로 높은 관절 모 멘트와 힘을 생산하는 능력의 제한을 야기시킬 수 있을 것으로 생각 된다. 본 연구의 결과는 일어서기 동작 시 하이힐 착용이 무릎관절의 운동형상학, 운동역학적인 움직임에 변화를 주어 관절 부하에 영향 을 미치고 있음을 알 수 있었다. 특히, 하이힐 착용 시 시상면의 무릎 관절 굽힘 각이 증가하였고, 앉은 자세에서 일어서기 동작의 서 있는 자세 시점에서 힘과 모멘트가 증가하였다. 이는 높은 굽 형태로 인한 발목관절의 발등 굽힘 움직임 제한이 일어서기 동작을 수행하기 위 해 보상작용으로 변화된 무릎관절 부하를 나타낸 것이라 생각된다.

본 연구 결과에서는 앉은 자세에서 일어서기 동작 시 하이힐 착용 으로 인한 여성의 잠재적인 퇴행성 무릎관절염 위험성 증가에 대한 새로운 시각을 제공하였으며, 특히, 무릎관절의 각도, 모멘트, 힘의 변 화는 노화와 골관절염 진행에서 나타나는 것과 유사하였음을 제시 할수 있다고 생각된다.

따라서, 관절 부하는 퇴행성 무릎관절염 발달 및 진행과 관련되어 있어 재활치료 부분에서 일어서기 동작을 수행하는 동안 다양한 형 태의 신발, 신발 깔창, 테이핑 등의 중재를 적용하여 무릎관절의 변형 된 관절 부하에 중점을 두어 감소시키는 것이 퇴행성 무릎관절염의 진행 정도를 지연시키는 데 효과가 있을 수 있음을 제시해볼 수 있다. 그러나 본 연구는 해당 시점에서만 값을 추출하여 결괏값을 얻어내 었고, 변형된 움직임 패턴과 근 동원 및 균형에 중점을 두지 않았기 
때문에 이러한 변화만으로는 하이힐이 무릎관절 부하에 미치는 영 향에 대해 결론 짓기에는 다소 부족함이 있었다. 또한 실험에 참여한 대상자의 수도 적었다. 그리하여 향후 연구에서는 더 많은 대상자들 로 하여금 근 동원 및 균형에 중점을 두어 이러한 변화 차이가 무릎 관절 연골과 스트레스에 어떠한 영향을 미치는지를 연구할 것이다.

\section{ACKNOWLEDGEMENTS}

This work was supported by research grants from the Catholic University of Daegu in 2014.

\section{REFERENCES}

1. McConnell J. The physical therapist's approach to patellofemoral disorders. Clin Sports Med. 2002;21(3):363-87.

2. Felson DT. An update on the pathogenesis and epidemiology of osteoarthritis. Radiol Clin North Am. 2004;42(1):1-9.

3. Kerrigan DC, Todd MK, Riley PO. Knee Osteoarthritis and high-heeled shoes. Lancet. 1998;351(9113):1399-401.

4. Kerrigan DC, Lelas JL, Karvosky ME. Women's shoes and knee osteoarthritis. Lancet. 2001;357(9262):1097-8.

5. Seong DY, Kim JH, Park JW. The effect of changes in foot cutaneous sensation on plantar pressure distribution during gait. J Kor Soc Phys Ther. 2012;24(5):306-12.

6. Kerrigan DC, Riley PO, Nieto TJ et al. Knee joint torques: A comparison between women and men during barefoot walking. Arch Phys Med Rehabil. 2000;81(9):1162-5.

7. Christina KA, Cavanagh PR. Ground reaction forces and frictional demands during stair descent: Effects of age and illumination. Gait Posture. 2002;15(2):153-8.

8. Kim DK. Change of walking and stair up in hemiplegia by proprioceptive neuromuscular facilitation techniques. J Kor Soc Phys Ther. 1999;11(3): 57-64.

9. Kim $\mathrm{MH}$, Yi CH, Yoo WG et al. EMG and kinematics analysis of the trunk and lower extremity during the sit-to-stand task while wearing shoes with different heel heights in healthy young women. Hum Mov Sci. 2011;30(3):596-605.

10. Edwards L, Dixon J, Kent JR et al. Effect of shoe heel height on vastus medialis and vastus lateralis electromyographic activity during sit to stand. J Orthop Surg Res. 2008;10:3:2.

11. Andriacchi TP, Andersson GB, Fermier RW et al. A study of lower-limb mechanics during stair-climbing. J Bone Joint Surg Am. 1980;62(5):74957.

12. Andriacchi TP, Galante JO, Fermier RW. The influence of total knee-replacement design on walking and stair-climbing. Journal of bone and joint surgery. J Bone Joint Surg Am. 1982;64(9):1328-35.

13. Kerrigan DC, Johansson JL, Bryant MG et al. Moderate-heeled shoes and knee joint torques relevant to the development and progression of knee osteoarthritis. Arch Phys Med Rehabil. 2005;86(5):871-5.

14. Lee CM, Jeong EH, Freivalds A. Biomechanical effects of wearing high- heeled shoes. Int J Indust Ergonom. 2001;28:321-6.

15. Stefanyshyn DJ, Nigg BM, Fisher V et al. The influence of high heeled shoes on kinematics, kinetics, and muscle EMG of normal female gait. J Appl Biomech. 2000;16:309-19.

16. Simonsen EB, Svendsen MB, Nørreslet A et al. Walking on high heels changes muscle activity and the dynamics of human walking significantly. J Appl Biomech. 2012;28(1):20-8.

17. Favre J, Erhart-Hledik JC, Andriacchi TP. Age-related differences in sagittal-plane knee function at heel-strike of walking are increased in osteoarthritic patients. Osteoarthritis Cartilage. 2014;22(3):464-71.

18. Shin HK, Ryu YU. The effects of seat surface inclination on the onset of muscle contraction during sit-to-stand in healthy adults. J Kor Soc Phys Ther. 2012;24(6):383-7.

19. Park MC, Lee MH. Analysis of muscle activity on foot position during a sit-to-stand activity in the elderly. J Kor Soc Phys Ther. 2011;23(1):1-5.

20. Boonstra MC, De Waal Malefijt MC, Verdonschot N. How to quantify knee function after total knee arthroplasty? Knee. 2008;15(5):390-5.

21. Su FC, Lai KA, Hong WH. Rising from chair after total knee arthroplasty. Clin Biomech (Bristol Avon). 1998;13(3):176-81.

22. Wretenberg P, Aborelius UP. Power and work produced in different leg muscle groups when rising from a chair. Eur J Appl Physiol Occup Physiol. 1994;68(5):413-7.

23. Kotake, T, Dohi N, Kajiwara T et al. An analysis of sit-to-stand movements. Arch Phys Med Rehab. 1993;74(10):1095-9.

24. Goulart FR, Valls-Solé J. Patterned electromyographic activity in the sitto-stand movement. Clin Neurophysiol. 1999;110(9):1634-40.

25. Barton CJ, Coyle JA, Tinley P. The effect of heel lifts on trunk muscle activation during gait: A study of young healthy females. J Electromyogr Kinesiol. 2009;19(4):598-606.

26. Titchenal MR, Asay JL, Favre J. Effects of high heel wear and increased weight on the knee during walking. J Orthop Res. 2015;33(3):405-11.

27. Roy G, Nadeau S, Gravel D. Side difference in the hip and knee joint moments during sit-to-stand and stand-to-sit tasks in individuals with hemiparesis. Clin Biomech (Bristol, Avon). 2007;22(7):795-804.

28. Palluel E, Ceyte H, Olivier I et al. Anticipatory postural adjustments associated with a forward leg raising in children: Effects of age, segmental acceleration and sensory context. Clin Neurophysiol. 2008;119(11): 2546-54.

29. Reilly DT, Martens M. Experimental analysis of the quadriceps muscle force and patello-femoral joint reaction force for various activities. Acta Orthop Scand. 1972;43(2):126-37.

30. Neumann DA. Kinesiology of the musculoskeletal system: foundations for physical rehabilitation. 2nd ed. St Louis, Mosby, 2009.

31. Sahrmann SA. Diagnosis and treatment of movement impairment syndromes. St Louis, Mosby, 2002.

32. Huberti HH, Hayes WC. Patellofemoral contact pressures. The influence of Q-angle and tendofemoral contact. J Bone Joint Surg Am. 1984; 66(5):715-24

33. Buff HU, Jones LC, Hungerford DS. Experimental determination of forces transmitted through the patella-femoral joint. J Biomech. 1988; 21(1):17-23.

34. Yoon JY, An DH, Yoo WG et al. Differences in activities of the lower extremity muscles with and without heel contact during stair ascent by young women wearing high-heeled shoes. J Orthop Sci. 2009;14(4):418- 
22.

35. Opila-Correia KA. Kinematics of High-Heeled Gait. Arch Phys Med Rehabil. 1990;71(5):304-9.

36. Ho KY, Blanchette MG, Powers CM. The influence of heel height on patellofemoral joint kinetics during walking. Gait Posture. 2012;36(2): 271-5.

37. Trepczynski A, Kutzner I, Bergmann G et al. Modulation of the relationship between external knee adduction moments and medial joint contact forces across subjects and activities. Arthritis Rheumatol 2014; 66(5);1218-27.
38. Jones RK, Chapman GJ, Parkes MJ et al. The effect of different types of insoles or shoe modifications on medial loading of the knee in persons with medial knee osteoarthritis: A randomised trial. J Orthop Res. 2015;19:doi:10.1002/jor.22947.

39. Nigg B, Herzog W. Biomechanics of the Musculo-Skeletal System. West Sussex, John Wiley \& Sons, 2007.

40. Tinetti ME, Ginter SF. Identifying mobility dysfunctions in elderly patients: Standard neuromuscular examination or direct assessment? JAMA. 1988;259(8):1190-3. 